\title{
Online-Learning and Students' Motivation: A Research Study on the Effect of Online Learning on students' motivation in IAIN Padangsidimpuan
}

\author{
Sri Minda ${ }^{1}$ \\ ${ }^{1}$ Institut Aagama Islam Negeri (IAIN) Padangsidimpuan, Indonesia
}

\begin{tabular}{|c|c|}
\hline ARTICLE INFO & ABSTRACT \\
\hline Article history: & \multirow{12}{*}{$\begin{array}{l}\text { An investigation was carried out to determine the strength of the } \\
\text { relationship between online-learning and students' motivation among } \\
\text { the students who participated in this research. The objective of the } \\
\text { research is to know whether online learning can increase the } \\
\text { students' motivation or not This research was conducted in State } \\
\text { Institute for Islamic Studies Padangsidimpuan in which } 100 \text { students } \\
\text { took part as the samples of the research. The samples of this research } \\
\text { were the students in Intensive Language Program IAIN } \\
\text { Padangsidimpuan. Questionnaire was applied to access the data from } \\
\text { the students participating in this process. The data was stattistically } \\
\text { computed by using Pearson's correlation coefficient. The findings of } \\
\text { this research proved that online-learning and students' motivation } \\
\text { have a weak correlation. Using Pearson Correlation Coefficient it } \\
\text { was found that r=0.156 is lower than r table = 0.5. This internet- } \\
\text { based learning poorly affected the students' willingness to learn. The } \\
\text { students were demotivated when they have to learn through online. } \\
\text { As a matter of fact, motivation is the most essential element in } \\
\text { influencing the students in learning virtually. This is happened } \\
\text { because of several reasons including lack of technology skill, poor } \\
\text { online learning designing, money and time consuming, and the } \\
\text { inadequate internet access }\end{array}$} \\
\hline Received 2 Aug 2020 & \\
\hline Revised 17 Aug, 2020 & \\
\hline Accepted 17 Sept, 2020 & \\
\hline Keywords: & \\
\hline Online Learning, & \\
\hline Students'motivation, & \\
\hline & \\
\hline Clonflict of Interest: & \\
\hline None & \\
\hline Funding: & \\
\hline None & \\
\hline
\end{tabular}

Corresponding Author: Sri Minda. IAIN Padangsidimpuan. E-mail: sriminda18@gmail.com.

(c) ()

1. Introduction

\subsection{Introduce the Problem}

The Conventional way of teaching in higher education especially in universities for a long period has been face to face classroom with a lecturer or professor delivering materials to students and the students listening and taking some important information. The interactions which are built by the professor and the students have been recognized as academic component in this instructional atmosphere.

The 21st century has seen rapid progress with such things as the Internet and online learning. The increased use of e-learning as instructional media leads a change in higher education. In line with a research finding, it is about 12-14 percent that the online learning enrolment rises per year: over five year period 2004-2009 (Brown and Liedholm, 2006). The primary reason of the increas is it provides the students more spaces to acsess greater information in comparison to traditional teaching methods as the students can undertake their tasks from any sources as well as being given them time flexibility (Harandi, Safiyeh Rajaee, 2015). The transformation of e-learning enables the students to share information in extremely easy way.

Many challenges faced by the traditional educators to answer the growing needs of the students. E-learning takes an important role in the process of instruction among the teachers and students in educational environment. Technology offers a lot of new applications that of course it is engaging for the students (Keller 
\& Suzuki, 2004). It is normal that new technologies suggest more interesting teaching media. Basic knowlegde of technology should be taught to the students and they have the ability to operate the technology at once to get the educational goals.

As the result of the technology expansion, e-learning has been used in a major way in many universities. Because of this reason, lecturers highly recommended to know how to use internet and the technology. Some educators have predicted that the traditional teaching will be finished. E-learing comes forward to lead the future education in main way to complete the weaknesses of traditional education pattern. E-learning makes everything possible, even with unlimited distance class (Haverila barkhi, 2009; Tamrakar \& K. Mehta, 2011).

Even though long-distance classroom already popular in education long before the internet expansion, ICT has become a primary device for any learning forms. The triplet web (World-Wide-Web) become an idol source to search any information or even as a learning device (Mahieu \& Wolming, 2013). The students' motivation in learning is encouraged by all these methods to produce more motivated learners. In achieving this aim, plenty of computer-based learning model developed as a way out to realistic educational problems.

The term "e-learning" is defined as internet-based learning (K.H. fee, 2005). K. Cheng (2006) stated the definition more common by pointing out that it is "anything expressed, enabled, or released by electronic technology for obvious purpose of learning" (S. Z. Keith, 1996). According to T. Fitzpatrick (2012) "e" does not stand for electronic in e-learning; it is supposed to an abbreviation for "evolving, enhanced, everywhere, every time and everyone." In reality, the quotation of shows most of the benefits of e-learning for students and lecturers (H.Li, 2009).

The covid-19 pandemic pushed all the aspects of human life become different. The effect of this situation brings the education must move from the way it has before. During the pandemic, people are not allowed to gather in a place to avoid the coronavirus infection. As the result, schools are closed. Students do not go to school and they must stay at home. E-learning is the only solution to keep the learning continuity. Because, of this the use of internet and technology rises significantly. All the teaching activity is done trhough online system including having classes, submitting task or homework, meeting, thesis advising and others academic activities. This situation cannot be avoided by higher education especially in IAIN Padangsidimpuan. The online learning has been constructed since the end of March 2020. The lecturers and students have the instructional through google classroom, zoom application, and at least whatsapp. As a matter of fact, elearning is not really popular implemented in this campus. Most of the lecturers administered the teaching in face-to-face classroom. Especially for those who have taught for more than 20 years, the teachig and learning process served in traditional way as the lecturer is explaining and the students take notes. Based on this fact, it is interesting to see if the students are motivated to learn by utilizing the e-learning. Although the elearning term and tools already exist for over a long period of time, the educational research related to this has not given enough interest to the study of student motivation in accordance with the effect of e-learning

\subsection{Explore Importance of the Problem}

It is crucial to conduct a research dealing with the problem stated previously. Since onliine learning is the top solution for teaching and learning in this pandemic era, it comes with some critical problems especially in IAIN Padangsidimpuan. Online learning is new trend in this campus after COVID-19 attacked the world. Many of the lecturers or even the students are not technowizard. So, that the online learning is less meaningful which is reasonable for the students to leave the online classes. From this reality, the researcher wanted to investigate the students' motivation and online learning. It was intended to know if online learning motivate or demotivate students to learn.

\subsection{Describe Relevant Scholarship}

A research deals with the implementation of e-learning towards the students' motivation found that the students' motivation to learn were increased by the interactive features of online learning of the undergraduate students. Students at the British University (BUE) and Helwan University in Egypt were the participant of the research. In supporting the conventional face to face classroom, both universities constructed e-learning as a learning tool. They use Moodle version 2.0 and higher (El-Seoud, et.al., 2014).

In accordance with e-learning, a study conducted by Brown and Liedholm's study (2006) showed that still have the same understanding of the lesson wether it is taught virtually or face to face course. Althought the students are online, they experience not different basic concept of a material. It is considered because the students spent less time working on the course. Surprisingly, online students got quite lower score on the task given by the lecturer. These results suggest spending more time on the task leads to deeper learning (Brown 
and Liedholm, 2006). In promoting deeper understanding of a concept, the lecturer should design more interesting online courses which can increase that can rise the students' motivation.

Moreover, a study investigated in educational planning at Allameh Tabatabei University, Tehran, Iran, reported some notable findings about online education. The hypotheses of the research were proved. The result shows that online learning has a deep relationship with students' motivation regardless to the ages and level of education. The findings confirm that when the teacher applied the online learning, the students' motivation zoomed significantly and vice versa (Harandi, Safiyeh Rajaee, 2015).

\subsection{State Hypotheses and Their Correspondence to Research Design}

As the explanation previously, the hyphothesis are formulated as follows:

1. Online learning significantly affects the students' motivation in learning

2. Online learning does not significantly affect the students' motivation in learning

\section{Literature Review}

\subsection{Online-Learning}

Online-learning is defined as an instructional process which uses technology to administer an education including training creation, learning content distribution, student-teacher communication, and other educational input processes (Wagnar, 2005). It is no paper learning instructional material which is delivered completely online. Using sophisticated communication and technology is a modern paradigm in education. Online-learning has been used massively especially in this pandemic time. All the school levels implement online learning.

Transferring education which includes skill and knowledge through an online network can be assumed as elearning. The education which is transfered can be received by a large number of people at the same of different times. This is known a well-built information system, but it does not give any spaces for human elemnt required in learning. It seems that the now the teacher's role is not an importer of knowledge anymore but it is changed become an expeditor of knowledge (Heverila \& Barkhi, 2009).

Online-learning as an entrance for more liberating students-teacher interactions, from limitations of time and space through the asynchronous and synchronous learning network model (Dillenbourg, et.al., 1995). Purposly used networked information and communication as a media to deliver knowledge or skill is considered as e-learning. A number of other terms are also used to describe this learning model such as online learning, virtual learning, and we-based learning. The letter "e" in E learning is abbreviated of electronic which means more than just online learning. The "e" intergrates all educational inputs that executed by individuals pr groups (Som Naidu, 2006). E-learning has the same meaning with "technologyenhanced learning (TEL), computer-based instruction (CBI), computer-based training (CBT), computerassisted instruction or computer-aided instruction (CAI), internet-based training (IBT), web-based training (WBT), online education, virtual education, virtual learning environments (VLE) (which are also called learning platforms), m-learning, and digital educational collaboration" (Obringer, 2002).

Some of adventages of applying online learning in education include unlimited access to search materials before tests, support of many learning styles and scheduling flexibility (Butler, 2010). It facilitates students and teachers to complete the learning in tehir own time and their fixed schedule.

A serious disadvantage of online courses is the upfront costs and time required to develop them (Berge, et. al, 2001). Another trend observed in online classes is an increased drop-out rate. The increased rate of student drop out speaks to the need to improve online learning environment design to increase student motivation and their active engagement in the course (Nash, 2005).

\subsection{Motivation to Learn}

One of the most notable parts in learning is motivation. The more motivation the better the student will be. Motivation can be interprated as the student's desire to learn something (Brophy, 2005). High intelligence does not guarantee a bright future, but it relies on the greater motivation which come from someone's desire. It is taken into consideration from that aspect, to be able to make the learner active and desirable in learning process gains importance.

Motivation is the key of learning. The motivation actually comes naturally from the interaction between the teacher and the student (Brophy, 2005). Therefore, the teacher role is one of the main parts in this process. If the students lack motivation, it does not mean that the problem come from the internal of the students 
themselves. So that, the teacher should realize how to get the students attention then finally boost their motivation

Motivation is a constructed theory that is used to explain persistence, initiation or intensity, especially self behavior. Motives are closely related to the aims from a set of actions. For example, a person find himself ill (motive), then by go to doctor's clinic (strategy) and get cure (goal). It is known that motives are human general needs or inclination that push people to do action on purpose. In contrast, goals (and related strategies) are more detailed and it can be used to describe the direction and quality of action in particular situations

\section{Method}

\subsection{Objective of The Research}

This research aimed to investigate if the use of online-learning in higher education leads to affect students' motivation in the field of learning. The goal of this research is to reflect the research objective and the findings which are focused on the students' motivation and the online learning influences

\subsection{Method of The Research}

Experimental research was carried out in this research. Students in the second semester of intensive language learning of IAIN Padangsidimpuan were the population in this research. The students were from different department of education. Statistical random sampling was used to get the sample of the research. There were 100 samples who involved in this process.

Questionnaire was administered to get the data from students. A standard motivation questionnaire was distributed to the students with 15 questions in it. Likert scale was applied to scale the questionnaire in which the scale between 1 to 5 ( $1=$ strongly disagree to $5=$ strongly agree). Statistical method Pearson's Correlation Coefficient was applied to analyze the data gained from the instrument of the data. The reliability of the questionnaire was examined by using cronbach Alpha.

The researcher investigated the correlation between the students scores and the students' motivation. The scores were taken from online class data. The online class has been started since March 2020. The data is computed by using SPSS.

Table 1. The Questionnaire Used in the Research

\begin{tabular}{cl}
\hline 1 & I like studying english through online learning \\
\hline 2 & $\begin{array}{l}\text { I think the teacher's ways of teaching through online learning assist me to improve my English } \\
\text { skills }\end{array}$ \\
\hline 3 & $\begin{array}{l}\text { I think the teacher's ways of teaching through online learning are not really useful in increasing my } \\
\text { English skills. }\end{array}$ \\
\hline 4 & I think my English score will be increased through online learning \\
\hline 5 & I can find more necessary information from online learning because I can surf the internet \\
\hline 6 & I hope online learning is sustainably used as educational platform \\
\hline 7 & I think online learning is updated learning platform \\
\hline 10 & Online learning is more interesting than face to face class \\
\hline 11 & I search more new knowledge in internet to support my online learning \\
\hline 12 & I think online learning is confusing and I do not understand the teacher's explanation \\
\hline 13 & I think the teacher's explanation through online learning is not really clear \\
\hline 14 & I always attend the online class \\
\hline 15 & I always have good internet connection during the online class \\
\hline 4 & Its and Dinceractions is enhanced during the online learning \\
\hline
\end{tabular}

\section{Results and Discussion}

\subsection{Result}


This research found that the online learning and students' motivation have a weak correlation. Technology is suppose to be a fun way to learn, but in this case it does not so. Most of the students were demotivated following online classes. As the result of this, the students' score during the online learning was low compared to their scores in face-to-face class especially listening and speaking. The computation using Pearson Correlation Coefficient with SPSS is presented in the following table.

Table 2. Correlation

\begin{tabular}{cccr}
\hline & & $\begin{array}{c}\text { Students' } \\
\text { English score }\end{array}$ & $\begin{array}{c}\text { Students' } \\
\text { motivation }\end{array}$ \\
\hline Students' English score & Pearson Correlation & 1 &, 156 \\
& Sig. (2-tailed) & 100 &, 668 \\
& $\mathrm{~N}$ &, 156 & 100 \\
\hline Students' motivation & Pearson Correlation &, 668 & 1 \\
& Sig. (2-tailed) & 100 & 100 \\
& $\mathrm{~N}$ & 100 & \\
& & &
\end{tabular}

Correlation is significant at the 0.05 level (2-tailed)

The Correlation between students' English score during online learning and the students' motivation resulted as $\mathrm{r}=0.156$. It means that the correlation between the two factors is weak. The level of significance used in this computation is at 0.5 (2-tailed). The result of the computation $r=0.156$ is lower than $r$ table $=0.5$. This finding also strengthen by the absence of symbol $\left(^{*}\right)$. If there is no symbol $(*)$ in the result, so it definitely presents that the correlation is weak.

\subsection{Discussion}

Online education grows rapidly, and information is enriched massively which makes education must follow all kinds of the improvements. This study has reported important finding on online learning and students' motivation. From the calculation using peaeson correlation coefficient, it is highlighted that the correlation between online learning and students' motivation is weak. Through the SPSS calculation the $r=0.156$ is lower than $\mathrm{r}$ table $=0.5$.

The finding reflects that the online learning does not waken the students' motivation. The students were not motivated although the online learning is a new trend in education recently. Online learning has been the only way out getting on with education since the Covid-19 attacked human life. Everybody at school age must deal with the technology touch in their education. Since the online learning is quite new educational platform in Padangsidimpuan, the teachers and the students were quite shocked with the use of this learning. The education system here is conventional in which the classes are face to face and teacher-centered learning. It is expressed form the result of the questionnaire (item no. 7) that online learning is a novelty for them. It is almost $90 \%$ (which is $88 \%$ ) who stated that they strongly agreed (scale 5) that this way is up to date.

In this case, the finding of the investigation proves that the students were not motivated learning with online space. The failure of online learning especially in this matter is not caused by a single simple problem. Many of reasons take part in influencing the motivation regression. Firstly, due to the teachers lack of technological literacy, the online learning seemed to be monotonous. The application used by the teachers mostly is Google Classroom. With only limited knowledge with the use of this platform, the teaching was less interactive and not creative. It can be proved by the students' statement in the questionnaire (item no. 1 to 5). The students responded to those items by scale 2 which is disagree for more than $80 \%$. This percentage describes that the teachers' presentation in teaching was discouraged the students willingness to learn. The teachers need to understand that the motivation is the main point of the success of online learning. However, it can be hard to rate up the students motivation with a limited digital knowledge. Moreover, new educational approaches must be adopted. Unfortunately, some teachers still remain unconvinced about the integration of technology into their learning process and are also reluctant to change their work patterns and teaching style. To help instructors during the transition period will require management support together with resources and sufficient time allocation. However, it is very difficult to quantify the precise nature of the change.

Enganging learning strategies however, influences the motivation. A study conducted at a university in the Midwest shows that self motivation is activated by active learning strategies. Self-reported motivation 
influenced selection of learning strategies more than any other factor (Oxford and Nyikos, 1989). More interesting online classroom activities should be created to meet the diverse student motivations. Multitasking can fulfill the different matiovations among the students. Given Oxford and Nyikos' (1989) theory regarding expressed motivation versus choice of learning strategies, educators who find a way to motivate students will also increase the likelihood students choose more active learning strategies to aid in facilitation of science concepts.

Secondly, a critical disadventage of online class is about costs and time which fundamentally effect the development of this system (Berge et. Al, 2001). Another investigation about this case presents that the increased rate of student drop out speaks to the need to improve online learning environment design to increase student motivation and their active engagement in the course (Nash, 2005).

Time and money are compulsory to guarantee the online learning route. therefore, it is important to determine their effectiveness as well as how to best develop them to make them more effective (Berge et. al, 2001). Teaching methodology in online learning is a new problem in education, even with highly motivated students (Tallent-Russels, et at, 2006). As a matter of fact, most of the students in IAIN Padangsidimpuan come from middle-low economical aspect which have not much time and money to get on this system anytime. During the online learning, it could be found that many of the students did not attend the class because they had no internet access or internet quota. Moreover, as they can learn out of school or campus, many of the students go with their parents to work. So that, they use their learning time to work. As the result of this, the students were absent as long as the online class time. This can be presented in the questionnaire (item no. 14) which is 28 out of $100(28 \%)$ students responded it by giving scale 3 . This reality is strengthen by a reseach conducted by Brown and Liedholldm in 2006. This research was carried out with undergraduate microeconomics students at the University of Michigan showed online learners spend less time working on class materials than students who attend a face-to-face class, which could attribute to less success in an online learning environment (Brown and Liedholdm, 2006).

Consolidating technology in the instruction process does not guarantee motivated students. As the matter of fact, personal relationship among the teachers and students gets stuck. The interaction of the teacher-students as well as students-students become less personal. The questionnaire litem no 9 and 10) present about the interaction among the teachers and students. It is resulted $76 \%$ students responded disagree with the statement. The students claimed that the interaction was not as intense as face-to-face class, even the responses from students who are considered as active responder was low. That percentage describes that only one fourth of the total number presented their agreement with this statement.

Motivation is the key of the success or failure of online learning. A study was carried out at Carnegie Mellon University (CMU) in America which shows that ther is a significant improvement on students' score through the online class. It is a prove that technolology does contibutes positively to education development.

It is contrary with the fact that students score during online classes were low. The pearson calculation shows that the online learning does not have a good relationship with motivation. It is described trhough the questionnaire (item no. 6). Over $90 \%$ students strongly disagreed (scale 1) with this statement. Most of the students do not want to keep fighting with online learning.

Although online instruction comes with several barriers, it does serve some positive opportunities for the students. For instance, online learning is like a flash transportation to bring the students around the world. The students can use additional cam to connect them everybody in the world. The students also can access unlimited materials to accomodate different students' need and learning styles (Butler, 2010). Resident students noted flexibility and convenience as the main reasons for enrolling in online courses at Penn State University (Pastore and Carr-Chellman, 2009).

Thirdly, inadequate internet access is the final reason making online classes did not work well in this reasearch. The students in IAIN Padangsidimpuan come from different areas in North Sumatera. Many of them live in the rural areas where internet access was limited. For instance, some students from isolated villages had to reach higher places such as mountain or hill in order to get internet access. They went to those places everyday and sometimes they found that the internet connection was bad. These internet barriers make students felt stressed out joining the class. As the result of this, their motivation to have online class got down.

Furthermore, as Covid-19 is a serious pandemic for human life now, online learning is the only way of keeping the students learn. It is noticeable that technology makes human life easier and online learning is a strong candidate to be a futuristic educational platform. But the finding of this research highlightes that 
onliine learning is not an idol learning for students in IAIN Padangsidimpuan. Online learning is something new for them which deals with some obstacles. In fact, the students who got involved in this process were not motivated following online class. They faced many meaningful problems during the online learning.

\section{Conclusion}

The success of online learning in higher education relies on the effectiveness of delivery and the students' motivation. An interesting online teaching does not guarentee that the students will be motivated to learn well and vice versa. Many factors which influence the students' motivation on online learning. The motivation of the students is influenced by either intrinsic or extrinsic factors.

Instructors need to have a good understanding about their student motivations

when teaching online classes. However, it is hard to assess student motivations for online learning due to the lack of personal contact between the students and instructor. In order to anticipate more serious problems, it is important for the instructors to learn more how to creat enganging online classroom rather than bored online discussion class.

Most importantly, it should be noted that more technology does not necessarily lead to better learning outcomes. The finding of this research proves that the students score during online learning came down. The decrease caused by demotivated students. Most of the students did not think that they were motivated with the learning. From the calculation using Pearson Correlation Ceofficient, it was gained that the correlation between online learning and students' motivation was absent. It can be said that online learning and students'motivation do not correlate each other in which online learning could not push the students to do more great educative initiations such as search for more explanations or materials, find more exercises, and read more e- book which relevant with their subject.

\section{Acknowledgements}

I am enormously grateful to Associate IAIN Padangsidimpuan for the permission conducting this research and my collegues for their kindly advices throughout my research.

\section{References}

Berge, Z. L. et. al. (2001). Web-based Training: Benefits and Obstacles to Succes. Englewood Cliffs, NJ: Educational Technology.

Brown, B. W, and L., C. E. (2002). Can Web Courses Replace The Classroom in Principles of Microeconomics? American Economic review, 1-12.

Butler, J. (2010). Techniques: Connecting Education and Careers. Online Learning: Lesson Learned., 32-36.

Dillenbourg, P., and S., D. (1995). Collaborative Learning and the Internet (Online document). http://tecfa.unige.ch/tecfa/research/CMC/colla/iccai95_1.html

El-Seoud, et. al. (2014). E-learning and Students' Motivation: A Research Study on the Effect of E-learning on Higher Education. http://dx.doi.org/10.3991/ijet.vgi4.3465

Harandi, S. R. (2015). Effects of E-learning on Students' motivation. Procedia-Social and Bahavioral Sciences, 3rd International Conference on Leadership, Technology and Innovation Management, 423-430.

Haverila Matti, et. al. (2009). The Influence of Experience Ability and Interest on e-learning Effectiveness. School of Business and Management, 1-13.

H. Li, J. Masters. (2009). E-learning nad Knowledge management in the Early Years: Where are we and where should we go. Knowledge Management and E-Learning: An International Journal, 4, 245 250 .

K, Cheng. (2006). A Research Study on Students' Level of Acceptance in Applying E-Learning for Business Courses- A case Study on a Technical College in Taiwan. Journal of American Academy of Business, 8, 265-270.

Keller John, et. al. (2004). Learner Motivation and E-learning Design: A Multinationally Validated Process. Journal of Education Media, Vol. 29, 229-239.

K.H., Fee. (2005). Delivering E-Learning: A Complete Strategy for Design Application and Assessment. Kogan Page. 
Mihieu Ron, et. al. (2013). Motives for Lifelong Learners to Choose Web-based Courses.

Naidu, S. (2006). E-Learning: A Guidebook of Principles, Procedures and Practices. file:///C:/Users/SRIMIN 1/AppData/Local/Temp/E Learning_Future_of_Education.pdf,

Nash, R. (2005). Course Completion rates among Distance Learners: Identifying Possible methods to Improve Retention. Online Journal of Distance Learning Administration, 4.

Obringer, L. A. (2002). How E-learning Works. http://www.howstuffworks.com

Oxford, R, and N., M. (1989). Variables Affecting Choice of language Learning Strategies by University Students. Modern Language Journal, 3, 291-300.

S. Z., Keith. (1996). Self-assessment materials for use in portofolios. 178-192.

Tallent, Russels, et. al. (2006). Teaching Courses Online: A Review of The Research.

T., Fitzpatrick. (2012). Key Success Factors of elearning in Education: A Professional development Model to Evaluate and Support eLearning. 789-795.

Wagner, J. (2005). Nebojme se elearningu. Ceska Scola, 174. 